\title{
Development of Agitators for Seeding Forages Using Air Delivery Systems
}

\author{
Duane McCartney, ${ }^{1}$ Gord Hultgreen, ${ }^{2}$ Allan Boyden, ${ }^{2 *}$ \\ and Craig Stevenson 3
}

\begin{abstract}
Authors are ${ }^{1}$ Pasture Management Research Scientist, Agriculture \& Agri-Food Canada, 6000 C \& E Trail, Lacombe, AB T4L 1W1, Canada; ${ }^{2}$ Agronomists, Prairie Agricultural Machinery Institute, Box 1150, Humboldt, SK, SOK 2A0, Canada; and ${ }^{3}$ Research Scientist, 142 Rogers Road, Saskatoon, SK S7N 3T6, Canada.
\end{abstract}

\begin{abstract}
Air seeders or air drills traditionally have been used for minimum till and direct seeding of cereal, oilseed, and pulse crops. These seeders use an air delivery system to move the seed from a large grain tank to cultivator furrow openers or boots. Air seeders have all the weight of the cultivator attachment on wheels, whereas the air drill cultivator attachment has the weight distributed to caster wheels on the front and the packer wheels on the back. These units have not been used extensively for forage seeding because of seed bridging problems with some types of grass seed over the metering system entry points in the seed tank. This study designed and evaluated modifications to the agitation and metering systems for seeding forages using 3 different types of Canadian-built air seeders. Meadow brome grass (Bromus riparius Rehmann) was used in the seeding trials because of its extreme susceptibility to bridging. The agitator systems for 3 different types of commercially available air seeders were modified with the ultimate goal to design a configuration that reduced seed bridging and provided uniform seed output. Tests were also conducted with a seed and fertilizer mixture as another method of improving uniformity of seed metering and output. None of the air seeders were able to meter and distribute pure meadow brome seed without the use of a modified agitation system. The Bourgault 3165 air seeder was able to effectively meter and distribute the meadow brome grass seed and fertilizer mixture without the agitator modifications and was able to meter and distribute pure meadow brome grass seed with the addition of the modified agitator. The Flexi-coil 172 air seeders required the addition of a horizontal agitator to effectively meter and distribute the seed and fertilizer mixture, and the Morris 6130 was unable to output the mixture of meadow brome grass seed and fertilizer uniformly despite agitator modifications. Field-scale testing indicated that grass forages could be successfully seeded using a fullsize air seeder with these modifications.
\end{abstract}

\section{Resumen}

Las sembradoras de aire o sembradoras en hileras de aire tradicionalmente han sido utilizadas en actividades de mínima labranza o siembra directa de cereales, oleaginosas o cultivos hortícolas. Estas sembradoras usan un sistema de aire para mover la semilla de un depósito grande de granos a los surcadores o las mangueras que depositan la semilla en las hileras. Las sembradoras de aire tienen todo el peso del implemento sobre las ruedas mientras que las sembradoras en hileras de aire tienen el peso distribuido en ruedas que abren la hilera en el frente y en ruedas compactadoras en la parte trasera. Estas unidades no han sido usadas extensivamente para la siembra de forrajes debido a que algunos tipos de semilla de zacates presentan problemas de atascamiento en los puntos de entrada del sistema de medición del tanque de semilla. Este estudio diseño y evaluó modificaciones a los sistemas de medición y agitación para la siembra de forrajes usando tres diferentes tipos de sembradoras de aire Canadienses. En los ensayos de siembra se utilizó el "meadow brome grass" (Bromus riparius Rehmann) debido a su extrema susceptibilidad a atascarse. Los sistemas de agitación para los tres diferentes tipos de las sembradoras de aire comercialmente disponibles fueron modificados con el objetivo de diseñar una configuración que reduzca el atascamiento de la semilla y provea una salida uniforme de esta. Las pruebas también se efectuaron con una mezcla de semilla y fertilizante como otro método de mejorar la uniformidad de la medición de la semilla y su salida. Ninguna de las sembradoras de aire fue capaz de medir y distribuir la semilla pura de "meadow brome grass" sin el uso de un sistema de agitación modificado. La sembradora de aire Bourgault 3165 fue capaz de medir y distribuir efectivamente la mezcla de semilla de "meadow brome grass" y fertilizante sin modificaciones al sistema de agitación y fue capaz de medir y distribuir la semilla pura de "meadow brome grass" con la adición del agitador modificado. Las sembradoras de aire Flexi-coil 172 requirieron de la adición de un agitador horizontal para medir y distribuir efectivamente la mezcla de semilla y fertilizante y la sembradora Morris 6130 fue incapaz de producir una salida uniforme de la mezcla de semilla de "meadow brome grass" y fertilizante, a pesar de las modificaciones del agitador. Las pruebas a nivel de campo indicaron que los zacates forrajeros pueden ser sembrados exitosamente usando una sembradora aire de tamaño completo con estas modificaciones.

Key Words: meadow brome grass, air seeder, agitation

${ }^{\star}$ Deceased.

Correspondence: Dr Duane McCartney, Agriculture \& Agri-Food Canada, 6000 C \& E Trail, Lacombe, AB T4L 1W1, Canada. Email: McCartneyD@agr.gc.ca

Manuscript received 21 May 2003; manuscript accepted 11 November 2004.

\section{INTRODUCTION}

Air seeders and air drills have become the seeding implement of choice for conservation tillage systems, including cereals, 


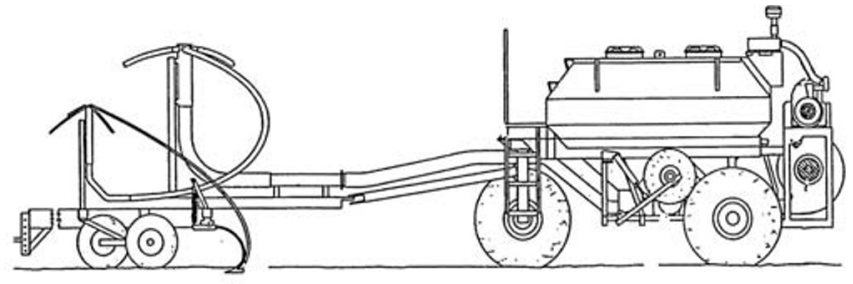

Diagram 1. Line Drawing of an Air Seeder

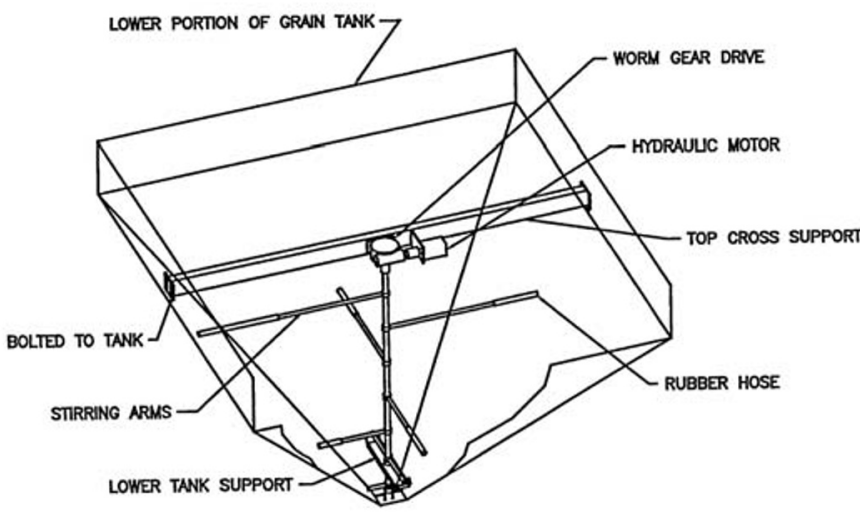

Diagram 2. Prototype of the agitator for the Bourgault air seeder.

Figure 1. Bourgault 3165 air seeder (Diag. 1) and schematic of the prototype agitator (Diag. 2).

oilseeds, and pulse crops, on most Canadian prairie farms because of their large seeding width (up to $18 \mathrm{~m}$ wide) and easy handling of seed and fertilizer (Fig. 1). Seed is delivered from a metering cup(s) at the bottom of a large seed tank into the air delivery system, which moves the seed to the various cultivator shank furrow seed openers or boots. Air seeders have all the weight of the cultivator on support wheels and no weight on the packer wheels, whereas the air drill cultivator attachment has the weight distributed to caster wheels on the front and the packer wheels on the back. Over the years, only the cultivator attachment has changed design, and the seed tanks and air delivery systems have remained the same. Because air seeders are the major seeding implement in Western Canada, range and pasture managers would like to use this type of equipment to seed new grasslands. However, these seeders have not been widely used for forage or rangeland seeding because some types of grass seeds are prone to bridging above the metering cup(s) in the seed tank (McCartney et al. 1997). Therefore, bridging can ultimately affect both the seeding rate and the uniformity of seed distribution among openers across the air seeder.

Farmers who have tried to seed grass with an air seeder have had to mix granular fertilizer with the seed to get the seed to flow through the air system. However, proper mixing of the fertilizer and seed is labor intensive, and improper mixing could result in pockets of high fertilizer concentration that could reduce seed germination (Middleton and McKenzie 1995; Solberg et al. 1995). The objectives of this study were 1) to assess the current forage seed handling characteristics of 3 popular Canadian air seeders and identify metering and output problems and 2) to develop agitation systems that result in uniform metering and output when forage seed is not mixed with fertilizer.

\section{MATERIALS AND METHODS}

\section{Lab Experiment}

Prairie Agricultural Machinery Institute (PAMI) evaluated Bourgault 3165, Morris 6130, and Flexi-coil 172 air seeders manufactured in Saskatchewan, Canada (McCartney et al. 1997; PAMI 1997). Meadow brome grass (Bromus riparius Rehmann) was used as the experimental material because it has rough awns that cause seed to bridge above the metering cups. The metering accuracy test for seed flow uniformity was conducted for each seeding implement by catching the seed samples under the end of the metering auger of the different airseeded units. This was done using pure seed and seed mixed with monoammonium phosphate $(4.5 \mathrm{~kg}$ meadow brome grass seed with $11.3 \mathrm{~kg}$ of monoammonium phosphate fertilizer) to determine if seed bridging occurred and consequently if there was a need for more effective agitation. Five different samples of pure meadow brome grass seed and the mixture of seed and fertilizer were collected in containers from the single-metering auger on the Bourgault air seeder. This metering auger distributes the seed into the air delivery system. The Morris and Flexicoil air seeders have 6 individual metering augers or metering cups and 3 different sets of samples of pure seed, and the mixture of seed and fertilizer were collected in containers from each of these cups. These samples were then individually weighed to determine consistency of seed distribution.

The seeding implements that were tested are designed specifically to seed cereals and oilseeds, not forage crops. Therefore, specific agitator modifications were necessary for each of the 3 different types of air seeders to prevent seed bridging. These modifications are discussed in more detail in the "Results and Discussion" section. Output was measured following agitator modifications for the seed-fertilizer mixture and pure meadow brome grass seed distribution into the air delivery system using 9 consecutive samples from the Bourgault, 6 from the Flexi-coil, and 4 consecutive samples from the Morris air seeder. These samples were collected prior to the pure seed and the seed-fertilizer mixture entering the air delivery system. Samples were individually weighed for each machine to determine consistency.

A second series of tests were performed to evaluate the distribution uniformity output at each seed opener at various air speeds $\left(6.8 \mathrm{~m} \cdot \mathrm{s}^{-1}-11.8 \mathrm{~m} \cdot \mathrm{s}^{-1}\right)$ and using the modified agitator on the Bourgault air seeder. Woven fiber bags were used to catch samples from each seed opener in 1 section of the seeding implements. Five consecutive samples were collected and weighed to assess uniformity of seed distribution.

Further tests were conducted at the request of the Flexi-coil manufacturer to determine the effect of field vibration on the accuracy of the metering system. The tests were conducted to determine if vibration would cause the seed and fertilizer mixture to separate, thus affecting uniformity of meadow brome output. The air seeder tank was shaken with a displacement of $25 \mathrm{~mm}$ at a rate of 120 cycles per minute with tire 
pressure at $35 \mathrm{kpa}$. Displacement was achieved with a motion generator placed under the rear axle near the left wheel. Seed was then collected in containers from beneath the Flexi-coil metering system and individually weighed for uniformity.

\section{Field Experiment}

A field-scale experiment was conducted in the spring on Ducks Unlimited land near Humboldt, Saskatchewan. A mixture of western wheatgrass (Agropyron smithii Rydb.), slender wheatgrass (Agropyron trachycaulum Link), green needle grass (Nassella vividula [Trin.] Barkworth), and northern wheatgrass (Agropyron dasystachyum Hook), in equal proportions as requested by Ducks Unlimited, was seeded at a rate of 13 $\mathrm{kg} \cdot \mathrm{ha}^{-1}$ with a full-size Bourgault 3165 air seeder $(12.6 \mathrm{~m})$ equipped with a floating hitch, hoe openers, mounted packers, and the modified agitator (Fig. 1). The Bourgault air seeder was chosen because the seeder could more accurately meter grass forage seed relative to the other implements in the lab experiments. The field (Black Chernozemic soil) had excellent moisture, as it had rained the night before and the 48-ha field had been previously worked prior to seeding with a tandem disc and then harrowed. Seeding was delayed until afternoon to allow the soil surface to dry. A small area of the field was also seeded with a mixture of the previously mentioned seed mixed with fertilizer $\left(13 \mathrm{~kg} \cdot \mathrm{ha}^{-1}\right.$ of seed and $33 \mathrm{~kg} \cdot \mathrm{ha}^{-1}$ of monoammonium fertilizer) to evaluate the effects on seed germination.

Seedling density was assessed in $31-\mathrm{m}^{2}$ areas (left, center, and right-hand side) of an implement pass at 10 different locations down the field where pure grass seed mix was sown and where seed-fertilizer mixture was sown. Areas with wheel tracks or other noticeable obstacles, such as large rocks, were avoided.

\section{Statistical Analysis}

All statistical analyses were conducted using the PROC MIXED procedure of SAS (Littel et al. 1996). Seed output data from the lab assessment of the different metering cups of the Flexi-coil and Morris systems were analyzed separately for each implement by drill configuration combination. The analysis was conducted as a randomized complete block design with different tests or runs as replicates. Seed output was compared among metering cups that occupied different positions on the metering system (e.g. extremity vs. center).

Seed output data from the lab assessment of different airflow rates for the Bourgault and Morris implements were analyzed separately for each system. The analysis was conducted as a randomized complete block design with openers as replicates. Seed output was compared among airflow rates.

Plant density data collected from the field demonstration experiment with the Bourgault 3165 were analyzed as a completely randomized design to assess the effect of fertilizer (pure seed or seed plus fertilizer) and frame position.

For each analysis, similar and different variance estimates for different levels of the treatment(s) were assessed. The loglikelihood parameter estimates for both models were compared with a restricted likelihood ratio test having a chi-square distribution to determine if variances differed. Treatment effects and variance component comparisons were declared significant at $P<0.05$.

\section{RESULTS AND DISCUSSION}

None of the air seeders were able to meter and distribute pure meadow brome without the use of agitation to prevent bridging above the seed metering system. Furthermore, each implement required modifications to its manufactured agitation system. Even with these modifications, only the Bourgault air seeder was able to successfully seed pure meadow brome grass seed.

\section{Bourgault 3165 Lab Results}

The Bourgault tank shape was not symmetrical. As a result, the factory-equipped solid steel agitator arm could not move seed from the corners. A vertical axis prototype agitator was constructed with 7 horizontal arms having rubber hose at the ends and 2 short vertical arms that extended into the transition area immediately above the seed metering auger (Fig. 1). These modifications prevented buildup in the corners and bridging above the metering auger under lab conditions and resulted in more uniform output with pure meadow brome seed and the seed-fertilizer mixture. The prototype vertical axis agitator did not improve output uniformity when meadow brome seed was mixed with fertilizer.

Pure meadow brome output from the Bourgault 3165 metering system (coefficient of variation $[\mathrm{CV}]=9 \%$ at mean $=$ $12 \mathrm{~kg}$ of seed $\cdot \mathrm{ha}^{-1}$ ) was within acceptable seeding equipment industry standards $(\mathrm{CV}<15 \%)$ when all agitator modifications were made (McCartney et al. 1997). Further testing was not done with a fertilizer mixture because acceptable results were obtained with the modified agitation with pure meadow brome seed. Output at the seed openers, with all agitator modifications in place and pure meadow brome as the metered product, increased slightly $(P=0.042)$ with greater airflow rates (Fig. 2$)$. Variability was statistically similar $(P>0.05)$ at the various airflow rates, and output variability across openers was always within industry standards.

\section{Bourgault 3165 Field Results}

Plant density slightly varied $(P=0.077)$ among frame and fertilizer mixture combinations when seeded with the Bourgault 3165 air seeder with the modified agitation system (Fig. 3). As a result, average plant density did not differ among left, center, and right frame sections for the grass seed or the seed and fertilizer mixture.

\section{Flexi-coil 172 Lab Results}

The Flexi-coil implement tank had 6 fluted-wheel metering cups located at the base of the seed tank and was factory equipped with a small finger-type agitator located above the metering cups. The agitator oscillated through a partial revolution. This agitation system did not prevent bridging of pure meadow brome grass. The agitator drive cam and fork drive were replaced with a chain drive to allow for a full rotation, and shorter fingers were installed in order to provide for rotational clearance. These modifications still did not prevent bridging above the agitator. As a result, a larger, more forceful horizontal agitator that included a hydraulic-powered horizontal rubber hose agitator arm rotating at $7 \mathrm{rpm}$ was installed above the primary agitator at each metering cup to improve seed flow into the metering cups. This modification did not 


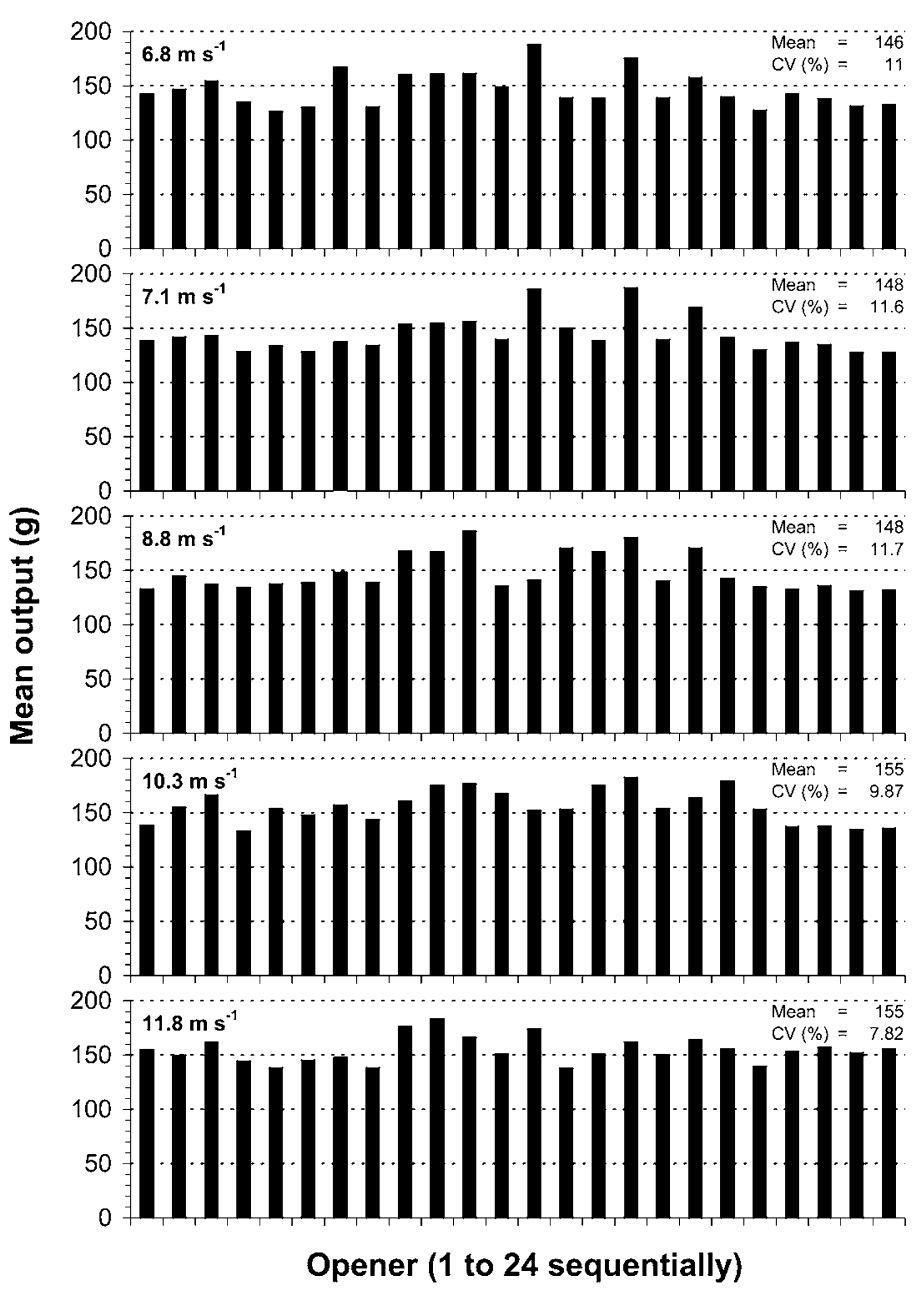

Figure 2. Pure meadow brome seed output for the Bourgault 3165 with agitation when tested across openers at different airflow rates.

improve the flow of pure meadow brome grass seed. Finally, extra fingers were added near the ends of the shaft of the Flexicoil agitator to improve seed flow to the outer metering cups. This additional modification did not improve seed metering uniformity.

Pure meadow brome output clearly could not be metered within the industry standard $(\mathrm{CV}<15 \%)$ with the Flexi-coil 1720 equipped with a standard agitation system and without simulated field vibration (Fig. 4). A more suitable agitator or a modified agitator will have to be developed in the future to meter pure meadow brome seed with the Flexi-coil implement. Mixing seed with fertilizer and all previously mentioned agitator modifications, without simulated field vibration, prevented bridging above metering cups, resulting in similar output among metering cups $(P=0.135)$ and industry-acceptable variability across replicates. The field vibration trial with each of the different modified agitation systems increased variability beyond the industry standard and resulted in varied output among metering cups $(P<0.05)$.

\section{Morris 6130 Lab Results}

The Morris 6130 air seeder had a rectangular-shaped seed tank with a long, narrow opening for the 6 fluted-wheel metering

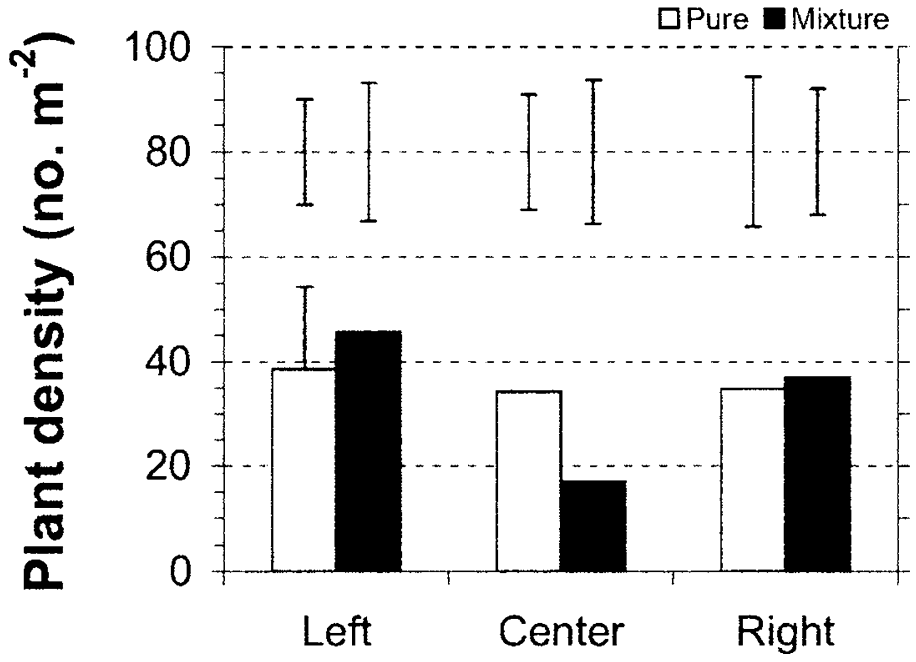

Figure 3. Mean plant density for the Bourgault 3165 with combinations of "Pure" seed or a "Mixture" (seed plus fertilizer) and different frame positions. Error bars with means represent $\mathrm{LSD}_{0.05}$ to compare stand for different treatment levels. Error bars above the preceding represent the coefficient of variation (CV), with each tick mark on the right-hand $y$-axis equaling 20 percentage units for $\mathrm{CV}$.

cups located across the bottom of the tank. The prototype agitator consisted of a vertical shaft and 2 horizontal arms mounted perpendicular to each other. A rubber hose was attached to the end of each arm to improve the movement of seed from the sides of the tank. A hydraulic motor rotated the agitator at about $7 \mathrm{rpm}$.

Pure meadow brome seed output clearly could not be metered within the industry standard $(\mathrm{CV}<15 \%)$ across replicates and resulted in statistically different output among metering cups $(P=0.017)$, with the Morris 6130 equipped with a modified agitation system (Fig. 5). Mixing seed with fertilizer resulted in statistically similar output among metering

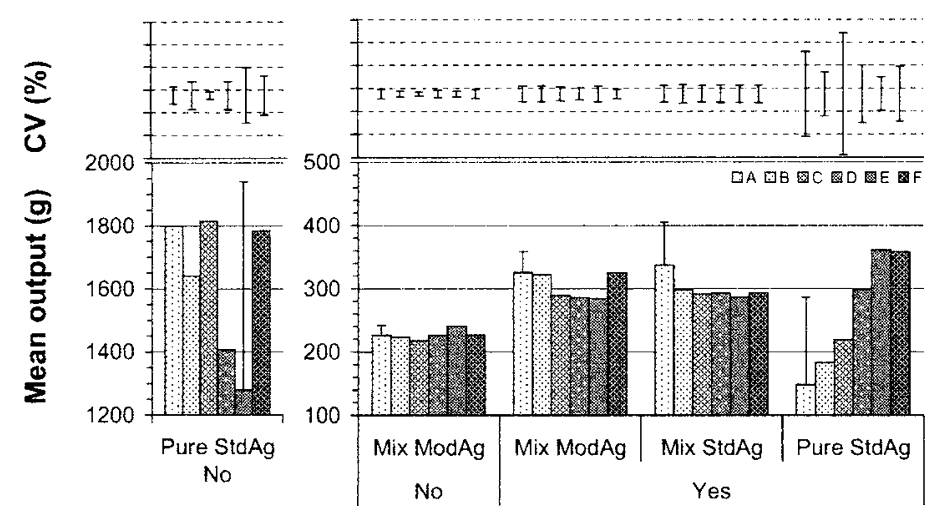

Figure 4. Meadow brome seed output of the Flexi-coil 1720 at different meter positions (A-F) for combinations of "Pure" seed or a "Mixture" (seed plus fertilizer), 2 agitator configurations ("StdAg": standard or ModAg: "Modified"), and simulated field vibration ("Yes" or "No") at the metering cups. Error bars with means represent $\mathrm{LSD}_{0.05}$ to compare output for different metering cups. Error bars in the top set of charts (each tick mark equals 20\%) represent the coefficient of variation $(\mathrm{CV})$. 


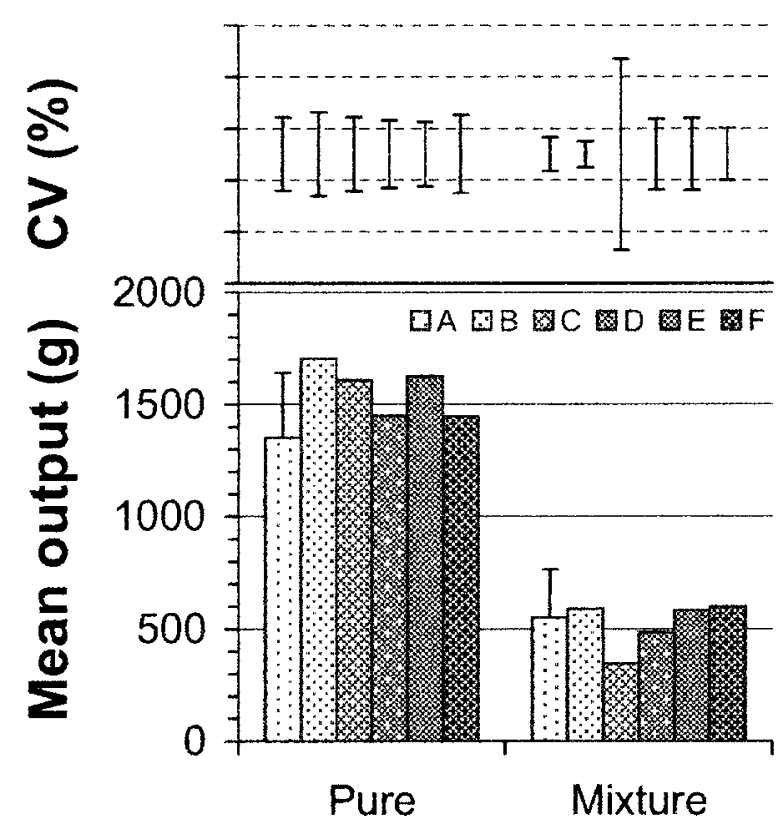

Figure 5. Meadow brome seed output of the Morris 6130 with agitation when tested for "Pure" seed or a "Mixture" (seed plus fertilizer) at the metering cups. Error bars with means represent $\mathrm{LSD}_{0.05}$ to compare output for different metering cups. Error bars in the top set of charts (each tick mark equals 20\%) represent the coefficient of variation (CV).

cups $(P=0.413)$ but could not be metered within the industrystandard level of variability. Output measured at the seed openers increased slightly $(P=0.030)$ as airflow increased, and variability among openers was statistically different $(P=0.004)$ at the greatest airflow rates, especially at $3800 \mathrm{rpm}$ (Fig. 6). Output variability at the seed openers was never within industry standards. More work needs to be done with the Morris agitation system to reduce the output variability when seeding forages either alone or in a mixture with fertilizer.

\section{CONCLUSIONS}

The Bourgault 3165 air seeder without agitator modifications and the Flexi-coil 172 air seeder with minor agitator revisions were able to deliver meadow brome grass seed and fertilizer mixtures at acceptable levels of variability. The Morris 6130 air seeder was unable to output the mixture of meadow brome grass seed and fertilizer uniformly despite agitator modifications. The Bourgault 3165 air seeder with the installation of a vertical agitator was the only seeder that allowed seeding of

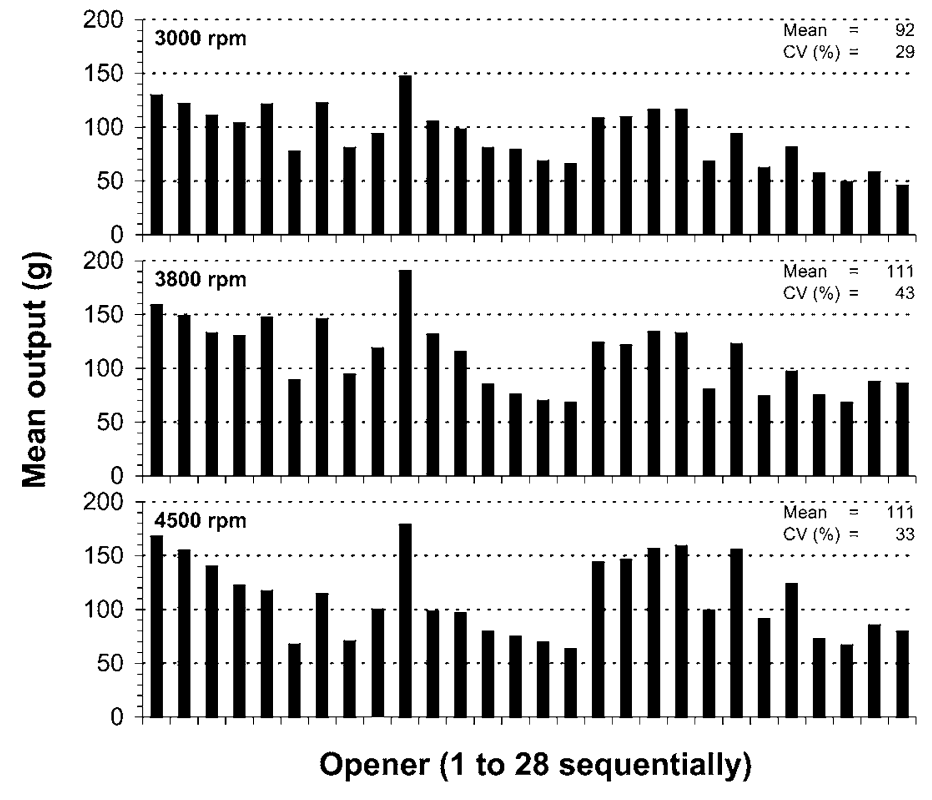

Figure 6. Pure meadow brome seed output for the Morris 6130 with agitation, tested across openers at different airflow rates.

pure meadow brome without bridging. The other air seeders had tank shapes and meter openings that were not as easy to agitate effectively and would require future specialized agitation modifications to allow them to handle pure grass seed without bridging. Other models of air seeders not tested in this study may be able to seed forages if the tank is square and open and has a large meter opening.

\section{LITERATURE CITED}

Littel, R. C., G. A. Milliken, W. W. Stroup, and R. D. Wolfinger. 1996. SAS system for mixed models. Cary, NC: SAS Institute. $656 \mathrm{p}$.

McCartney D., A. Boyden, G. Hultgreen, P. Leduc, and J. Wassermann. 1997. Improving the air seeding of meadow brome grass. Humboldt, SK, Canada: Prairie Agricultural Machinery Institute. PAMI Project RH0793. 37 p.

Middleton, A. B., and R. H. McKenzie. 1995. Optimal placement of fertilizer on barley, canola and wheat. Edmonton, AB, Canada: Alberta Agriculture Research Institute. Summary Report Southern Plots, Alberta Agriculture Research Institute 95-040. $42 \mathrm{p}$.

[PAMI] Prairie Agricultural Machinery Institute. 1997. Air seeding forage crops. Humboldt, SK, Canada: PAMI. Research Update 733. 4 p.

Solberg, E., D. C. Penney, R. H. McKenzie, J. Harapiak, and N. Flore. 1995. Optimal seed placed fertilizer with air seeded/direct seeded crops. Edmonton, $A B$, Canada: Agronomy Unit, Alberta Agriculture Food and Rural Development. Annual Report. $8 \mathrm{p}$. 